\title{
Design of Infiltration Well in Wetlands Area that Suitable for Giving Maximum Groundwater Recharge
}

\author{
IRFAN PRASETIA \\ Dept. of Civil Engineering, Faculty of Engineering, \\ Lambung Mangkurat University
}

\begin{abstract}
Growth in residential, industrial, and office area,are significantly occurred in all city in Indonesia. Unfortunately, this is also caused more land that being covered by pavement and concrete in the cities. Realized or not it will disturb the availability of the groundwater and also lead to flooding in the rainy season. One of the effective solutions to solve this problem is by making sufficient numbers of infiltration well in the city, especially in the residential area. This research was conducted to analyze the ideal design of the infiltration well in the residential area. The design was made according to the equation by Sunjoto, which also refers to Indonesia standard (SNI) No: 03-2453-2002. The results show that the ideal dimension for the infiltration well is to use the radius of the well $(\mathrm{R})$ of $1.25 \mathrm{~m}$. With the $\mathrm{R}$ of 1.25 will give a significant recharge to the groundwater as much as $\approx 2.400$ liter. It is expected that this research encourage a development in the urban drainage systems which will consider the environment and the groundwater reservation for the balance of our ecosystem.
\end{abstract}

Keywords : infiltration well, groundwater reservation, ecosystem balance.

\section{INTRODUCTION}

Nowadays, flooding has become a routine agenda that occurred in several big cities in Indonesia. A fast growth of cities in Indonesia is one of the causes of this problem. New residential, industrial, and office area that opened made the water catchment area become smaller. This condition can lead to imbalance in the ecosystem which will cause to surface runoff, erosion, and lack of groundwater reservation.

According to the conventional concept, urban drainage system is only trying todrain the water from the flooded area to the river, retention areas and/or sea. This system will only move the puddles from one place to another place. Thus, new concept that is being developed nowadays is a drainage system which is environmentally friendly which so called as eco-drainage system.

Correspondence: Irfan Prasetia, Dept. of Civil Engineering, Faculty of Engineering, Lambung Mangkurat University.

Email: prasetia.07@gmail.com
An effective solution that can be offered through this eco-drainage system is by making the infiltration well.The infiltration well can recharge the ground water by injecting the rain water to the soil. The area that need this infiltration well such as farming area, residential, industrial, office area, and another public service areas. For the infiltration well's design in the residential area has to comply to the Indonesia standard (SNI) No: 03-2453-2002 (Litbang Pemukiman PU, 1990). This standard define how to design the infiltration well for residential yards, including the general and technical requirements regarding the ground water level limit, the value of the permeability of the soil, the distance of the building, the calculation and determination of the infiltration well. However, this standard has not yet determines the ideal design for infiltration well.

Therefore, this research obtective is to determine the ideal design infiltration well in the residential area. The design was made according to the equation by Sunjoto (1993), which also refers to Indonesia standard (SNI) 
No: 03- 2453-2002. It is expected that this research will encourage a development in the urban drainage systems which will consider the environment and the ground water reservation for the balance of our ecosystem.

\section{METHODS}

The design was made according to the equation by Sunjoto (1993). To facilitate the research works, the residential area of Lambung Mangkurat University's lecturer at Banjarbaru city, South Kalimantan Province, Indonesia, was chosen. As for the equation, these data have been set as the reference:

1. the roof surface area: ranged between 50 $\mathrm{m}^{2}$ until $1.000 \mathrm{~m}^{2}$

2. the radius of the well $(\mathrm{R})$ : ranged between $0,5 \mathrm{~m}$ until $1,5 \mathrm{~m}$

3. the depth of the infiltration well:

$$
H=\frac{Q}{F K}\left[1-\exp \left(\frac{-F K T}{\pi R^{2}}\right)\right]
$$

where: $\mathrm{H}=$ Water level in the well (m) $\left(\mathrm{m}^{3} / \mathrm{hr}\right)$,

$\mathrm{Q}=$ Discharge of rainwater

$\mathrm{F}=$ Geometric factor $(\mathrm{m})$,

$\mathrm{K}=$ Soil permeability value $(\mathrm{m} / \mathrm{hr})$

$\mathrm{T}=$ Dominant rainfall duration $(\mathrm{hr})$

$\mathrm{R}=$ radius of the well $(\mathrm{m})$

4. The geometric factor:

For impermeable wall of the infiltration well is

$\mathrm{F}=2 \pi \mathrm{R} \quad$ (eq. 2)

\section{RESULTS AND DISCUSSIONS}

\section{Hydrology Data}

Hydrology data of the research works area was taken from the community service report of the lecturer team of the Faculty of Engineering Unlam Banjarbaru (Shadiq et al, 2006). The data that being obtained from the team are:

1. The maximum discharge of rainwater (Qp) according to rational method:

$$
\begin{aligned}
\text { Qp } & =0,002778 \cdot \mathrm{C} \cdot \mathrm{I} \cdot \mathrm{A} \\
& =0,002778 \cdot 0,1 \cdot 356,7 \cdot \mathrm{A} \\
& =0,099 \mathrm{~A} \mathrm{~m}^{3} / \mathrm{sec}
\end{aligned}
$$

where:

Qp =The maximum discharge of rainwater,

C = Roof surface flow coefficient,

I = Rain intensity,

A $=$ Roof surface area

2. Dominant rainfall duration

According to the Kirpich method, with length of the trench $=0.016 \mathrm{~km}$ and the river slope $=0.05 \mathrm{~m} / \mathrm{m}$, then the calculation for the Dominant rainfall duration $(\mathrm{T})$ is 0.5 hours.

3. Permeability (K)

Value of the average permeability of the soil in the research works area is $1.23 \times 10^{-3}$ $\mathrm{cm} / \mathrm{secor} 4 \mathrm{~cm} / \mathrm{hr}$ or $0.04 \mathrm{~m} / \mathrm{h}$. This value is in accordance to the requirement value that specified in the SNI No: 03-2453-2002 with the soil permeability value more than $2.0 \mathrm{~cm} / \mathrm{hr}$. Thus, this area is suitable for designing the infiltration well.

\section{Design of the infiltration well}

With the hydrology data that already mentioned above, the depth of the infiltration well can be calculated according to the eq.1. The calculation can be seen in Table 1. In addition, maximum volume of the infiltration well can be seen in Table 2 .

From Table 1, with the radtus of the well ranging between $1 \mathrm{~m}$ until $1.5 \mathrm{~m}$, the depth of the well is below $1 \mathrm{~m}$. Thus,with a depth of less than $1 \mathrm{~m}$ will facilitate the process of excavation. Therefore, the radius of the well between $1 \mathrm{~m}$ until $1.5 \mathrm{~m}$ is an ideal dimension for the depth of the infiltration well. Furthermore, according to the Table 2, it could be seen that the difference in the maximum volume of the infiltration well between $\mathrm{R}=1.25 \mathrm{~m}$ with $\mathrm{R}=1.5 \mathrm{~m}$ is not significant. Thus, it is more efficient to use $\mathrm{R}$ $=1.25 \mathrm{~m}$. 
Table 1 Calculation of the depth of the infiltration well

\begin{tabular}{cccccc}
\hline $\begin{array}{c}\text { Roof surface } \\
\text { area }(\mathrm{A}) \mathrm{m}^{2}\end{array}$ & $\mathrm{R}=0,5 \mathrm{~m}$ & $\mathrm{R}=0,75 \mathrm{~m}$ & $\mathrm{R}=1 \mathrm{~m}$ & $\mathrm{R}=1,25 \mathrm{~m}$ & $\mathrm{R}=1,5 \mathrm{~m}$ \\
\cline { 2 - 5 } & 3.0285 & 1.3639 & 0.7723 & 0.4962 & 0.3455 \\
50 & 6.0571 & 2.7277 & 1.5445 & 0.9925 & 0.6910 \\
100 & 9.0856 & 4.0916 & 2.3168 & 1.4886 & 1.0366 \\
200 & 12.1140 & 5.4554 & 3.0891 & 1.9849 & 1.3821 \\
250 & 15.1425 & 6.8194 & 3.8613 & 2.4811 & 1.7276 \\
300 & 18.1711 & 8.1833 & 4.6336 & 2.9774 & 2.0731 \\
350 & 21.1996 & 9.5471 & 5.4059 & 3.4735 & 2.4186 \\
400 & 24.2281 & 10.9110 & 6.1781 & 3.9697 & 2.7640 \\
450 & 27.2566 & 12.2748 & 6.9504 & 4.4660 & 3.1097 \\
500 & 30.2852 & 13.6387 & 7.7227 & 4.9622 & 3.4552 \\
550 & 33.3136 & 15.0026 & 8.4949 & 5.4585 & 3.8006 \\
600 & 36.3421 & 16.3664 & 9.2672 & 5.9546 & 4.1461 \\
650 & 39.3706 & 17.7303 & 10.0395 & 6.4509 & 4.4916 \\
700 & 42.3992 & 19.0941 & 10.8117 & 6.9471 & 4.8373 \\
750 & 45.4277 & 20.4581 & 11.5840 & 7.4434 & 5.1827 \\
800 & 48.4562 & 21.8220 & 12.3563 & 7.9395 & 5.5282 \\
850 & 51.4848 & 23.1858 & 13.1285 & 8.4357 & 5.8737 \\
900 & 54.5133 & 24.5497 & 13.9008 & 8.9320 & 6.2192 \\
950 & 57.5417 & 25.9135 & 14.6731 & 9.4282 & 6.5648 \\
1000 & 60.5702 & 27.3003 & 15.4453 & 9.9245 & 6.9103 \\
\hline
\end{tabular}

Table 2. Maximum volume of the infiltration well

\begin{tabular}{ccccccc}
\hline \multirow{2}{*}{$\begin{array}{c}\text { Roof surface } \\
\text { area }(\mathrm{A}) \mathrm{m}^{2}\end{array}$} & \multicolumn{2}{c}{$\mathrm{R}=1 \mathrm{~m}$} & \multicolumn{2}{c}{$\mathrm{R}=1,25 \mathrm{~m}$} & \multicolumn{2}{c}{$\mathrm{R}=1,5 \mathrm{~m}$} \\
\cline { 2 - 7 } $\mathrm{H}(\mathrm{m})$ & $\mathrm{V}(\mathrm{l})$ & $\mathrm{H}(\mathrm{m})$ & $\mathrm{V}(\mathrm{l})$ & $\mathrm{H}(\mathrm{m})$ & $\mathrm{V}(\mathrm{l})$ \\
\hline 50 & 0.7723 & 2425.022 & 0.4962 & 2434.481 & 0.3455 & 2440.958 \\
100 & 1.5445 & 4849.73 & 0.9925 & 4869.453 & 0.691 & 4881.915 \\
150 & 2.3168 & 7274.752 & 1.4886 & 7303.444 & 1.0366 & 7323.579 \\
200 & 3.0891 & 9699.774 & 1.9849 & 9738.416 & 1.3821 & 9764.537 \\
250 & 3.8613 & 12124.482 & 2.4811 & 12172.897 & 1.7276 & 12205.494 \\
300 & 4.6336 & 14549.504 & 2.9774 & 14607.869 & 2.0731 & 14646.452 \\
350 & 5.4059 & 16974.526 & 3.4735 & 17041.859 & 2.4186 & 17087.409 \\
400 & 6.1781 & 19399.234 & 3.9697 & 19476.341 & 2.764 & 19527.660 \\
450 & 6.9504 & 21824.256 & 4.466 & 21911.313 & 3.1097 & 21970.031 \\
500 & 7.7227 & 24249.278 & 4.9622 & 24345.794 & 3.4552 & 24410.988 \\
550 & 8.4949 & 26673.986 & 5.4585 & 26780.766 & 3.8006 & 26851.239 \\
600 & 9.2672 & 29099.008 & 5.9546 & 29214.756 & 4.1461 & 29292.197 \\
650 & 10.0395 & 31524.03 & 6.4509 & 31649.728 & 4.4916 & 31733.154 \\
700 & 10.8117 & 33948.738 & 6.9471 & 34084.209 & 4.8373 & 34175.525 \\
750 & 11.584 & 36373.76 & 7.4434 & 36519.181 & 5.1827 & 36615.776 \\
800 & 12.3563 & 38798.782 & 7.9395 & 38953.172 & 5.5282 & 39056.733 \\
850 & 13.1285 & 41223.49 & 8.4357 & 41387.653 & 5.8737 & 41497.691 \\
900 & 13.9008 & 43648.512 & 8.932 & 43822.625 & 6.2192 & 43938.648 \\
950 & 14.6731 & 46073.534 & 9.4282 & 46257.106 & 6.5648 & 46380.312 \\
1000 & 15.4453 & 48498.242 & 9.9245 & 48692.078 & 6.9103 & 48821.270 \\
\hline
\end{tabular}

Based on calculation showed in the Table 1 and 2, it can be concluded that the ideal design for the infiltration well that can be build in the residential area is by using $\mathrm{R}=$ $1,25 \mathrm{~m}$. With this $\mathrm{R}$ value, it can make the building process of the infiltration well easier. In addition, with this $\mathrm{R}$ value will also facilitate the process of excavation which is not to deep and wide. Therefore, it is easy to build this infiltration well and structurally safe. In addition, with the $\mathrm{R}$ of $1.25 \mathrm{~m}$ will give a significant recharge to the groundwater as much as $\approx 2.400$ liter. 


\section{CONCLUSIONS}

In accordance with the purposes of this study, the ideal design of the infiltration well has been determined. Based on the data and from the analysis of these data, there are several things that can be drawn as a conclusion from this study as follows:

1. The hydrology data that obtained from the field show that the maximum discharge of rainwater $(\mathrm{Qp})$ is $0,099 \mathrm{~A} \mathrm{~m} 3 / \mathrm{sec}$ and value of the average permeability of the soil is 4 $\mathrm{cm} / \mathrm{hr}$. Thus, this area is suitable for designing the infiltration well which the requirement value that specified in the $\mathrm{SNI}$ No: 03-2453-2002 is more than $2,0 \mathrm{~cm} / \mathrm{hr}$.

2. The analyses of the data show that the ideal design for the infiltration well build in the residential area is by using the radius of the well $(\mathrm{R})$ of $1.25 \mathrm{~m}$. With this $\mathrm{R}$ value will facilitate the process of excavation and also structurally safe.
3. According to this study, the infiltration well will give a significant recharge to the groundwater as much as $\approx 2.400$ liter for the roof surface area equal as $50 \mathrm{~m}^{2}$, until as much as $\approx 48.000$ for the roof surface area equal as $1.000 \mathrm{~m}^{2}$.

\section{REFERENCES}

Shadiq, F., et al. (2006). Penerapan Sistem Drainase Lingkungan di Kampus UNLAM Barjarmasin dan Banjarbaru. Laporan Pengabdian Masyarakat. Banjarmasin: LPM UNLAM

Litbang Pemukiman PU (1990). Tatacara Perencanaan Teknik Sumur Resapan Air Hujan Untuk Lahan Pekarangan Standart. Bandung : Departemen Pekerjaan Umum Sunjoto. (1993).Kehilangan Air Disaluran. Makalah disajikan dalam Laporan Penelitian UGM, Yogyakarta 